\title{
The Impact of Industrial Sector on Poverty Reduction in all Provinces of Iran
}

\author{
Shaban Mostafaei ${ }^{1}$ \\ Farhad khodadad-Kashi \\ Yeganeh Mosavi Jahromi ${ }^{3}$
}

\author{
mostafaee@pnu.ac.ir \\ khodadad@pnu.ac.ir \\ mosavi@pnu.ac.ir
}

\begin{abstract}
This paper examines the impact of industrial sector on poverty reduction in all provinces of Iran. For this purpose, squared poverty gap index (FGT(2)) was first measured in the urban areas of provinces; Then the value added of those industrial activities that are carried out by ten or more employees are gathered at the ISIC 2-digit code level. Finally, using Panel-VAR approach, the impacts of industrial sector on poverty in all provinces of Iran were evaluated for the period (2004-2015). The results indicate that in those provinces which have high levels of productivity in industrial workshops, poverty intensity is low. Therefore, at high level of productivity of industrial workshops, there is a significant relationship between industry and poverty. The results also show that with regard to causal relationship, poverty is not the Granger-cause of industry growth; also, the added value shock of industrial activities had no impact on poverty at the moment of shock occurrence. Moreover, in the analysis of variance, the value added of industrial activities does not explain the as much of intensity of urban poverty as much. Therefore, the results of applying the panel-VAR approach indicate the small impacts of the value added of industrial activities with ten employees and more on the severity of urban poverty. These findings can be used in developing executive and research strategies.
\end{abstract}

Keywords: Poverty Severity, Value Added of Industry, Panel VAR Approach, Pro ductivity of Industrial Workshops, Granger Causality.

JEL Classification: L5, O1, R1.

1. Ph.D. Student of Economics, Payam Noor University Tehran, Iran (Corresponding Author).

2. Professor, Department of Economics, Payam Noor University Tehran, Iran.

3. Professor, Department of Economics, Payam Noor University Tehran, Iran. 


\section{بررسى تاثير بخش صنعت بر كاهش فقر در كل استانهاى ايران}

mostafaee@pnu.ac.ir

khodadad@pnu.ac.ir

mosavi@pnu.ac.ir

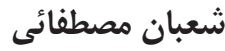

دانشجوى دكترى اقتصاد، دانشًاه ييامنور تهران (نويسندهمسئول).

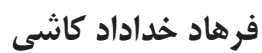

إستاد كروهاقتصاه، دانشكاه بيام نور.

يكانه موسوى جهرمى المادي

استاد گروه اقتصاد، دانشعاه يِيام نور.

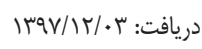
جֶيده: در اين يروهش، تاثير بخش صنعت بر كاهش فقر در كل استانهاى ايران بررسى

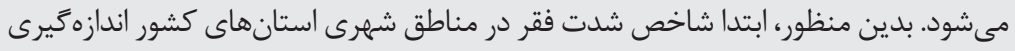

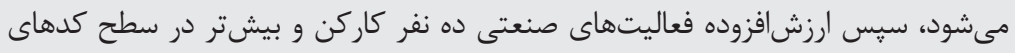

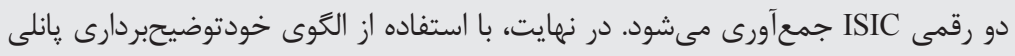
(Panel-VAR)

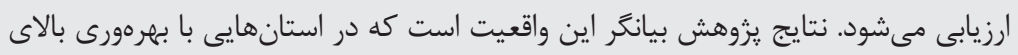

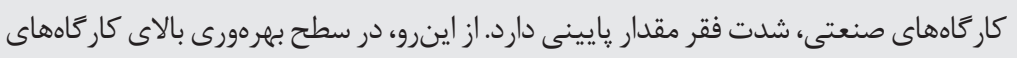

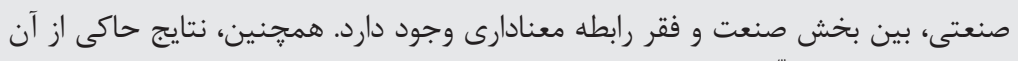

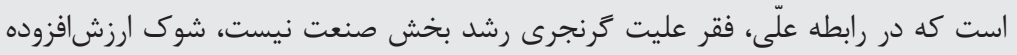

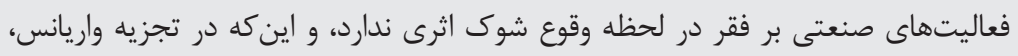

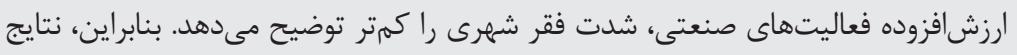

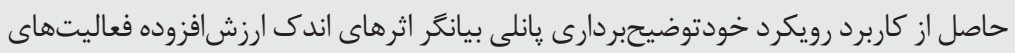

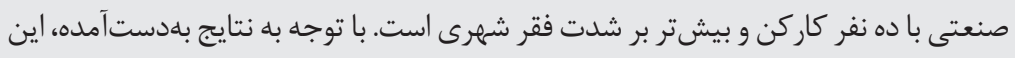

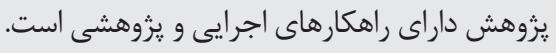

كليدوازهها: شدت فقر، ارزشافزوده صنعت، رويكرد Panel-VAR، بهرهورى كارگاههاى صنعتى، عليت گرنجرى. طبقهبندى REL: : R1, O1, L5. 
در بررسى موقعيت كشورهاى توسعهنيافته، يديده فقر به عنوان يكى از بارزترين ويزَّى هاى اين

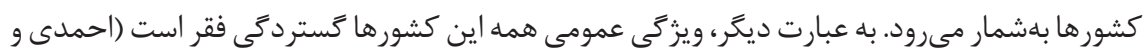

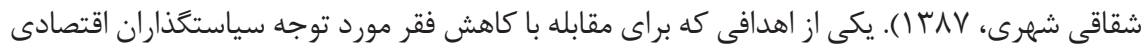
قرار گرفته، رشد اقتصادى هست. اما در مورد اينكه رشد اقتصادى فقر را كاهش مىدهد، مناقشه

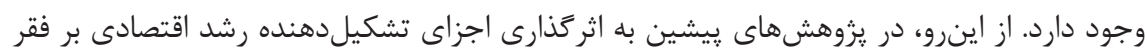

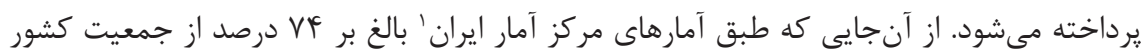

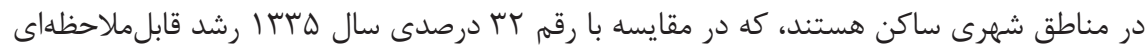

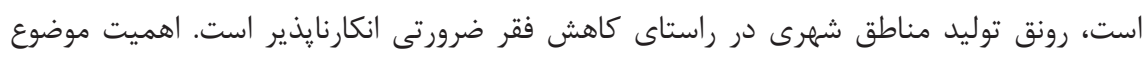

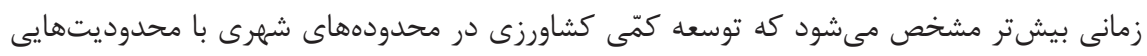

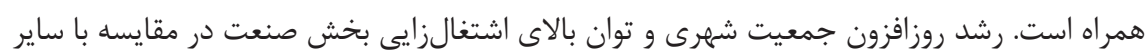

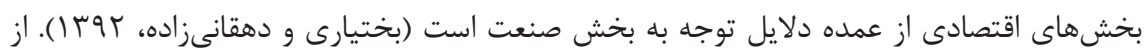

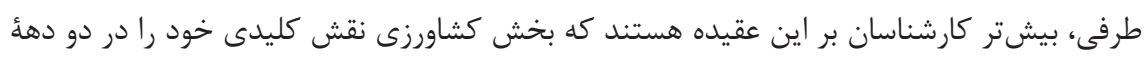

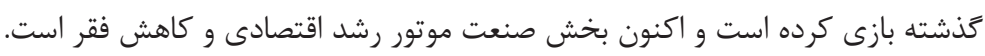

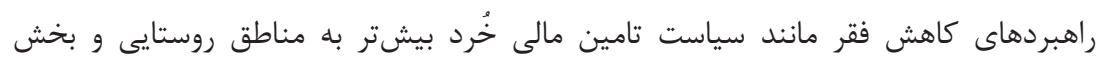

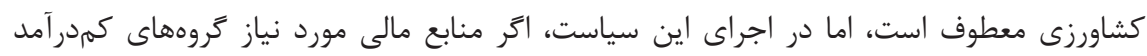

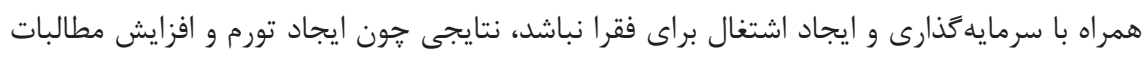

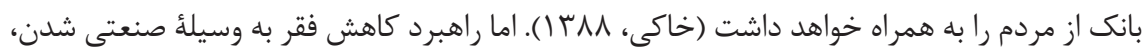

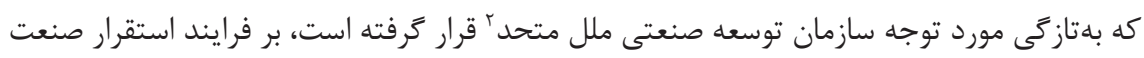

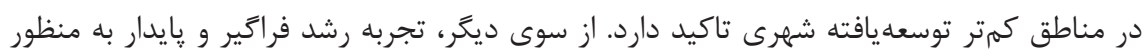

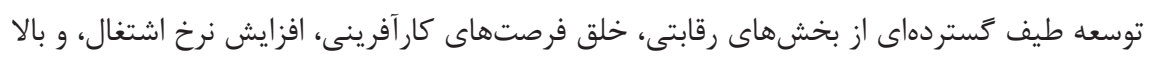

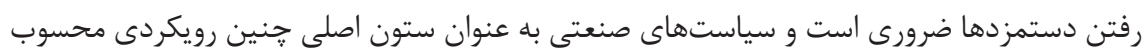

ميشوند (Khan, 2015).

با توجه به آنجه بيان شد، در اين يزوهش براى بررسى راهبرد كاهش فقر به وسيلهُ صنعتى شدن

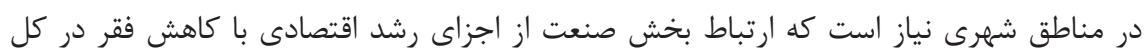

2. United Nations Industrial Development Organization (UNIDO) 
استانهاى كشور بررسى شود؛ تا به اين يرسش مهرم ياسخ داده شود كه آيا بخش صنعت ظرفيت لازم

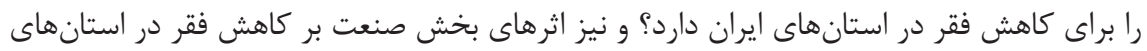

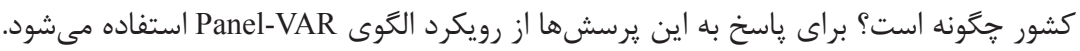

از جمله راهبردهاى توسعهاى بكار رفته توسط كشورهاى درحالتوسعه، صنعتى شدن است.

در اين راهبرد بر رشد اقتصادى با ابزار گسترش سريع بخش صنعت تاكيد مىشود. اهميت بخش

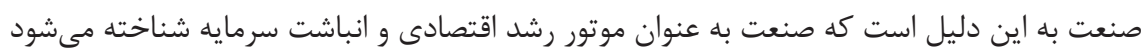
و بخشى است كه منبع بازدهى فزاينده نسبت به مقياس توليد دارد. برخى از دانشمندان توسعه

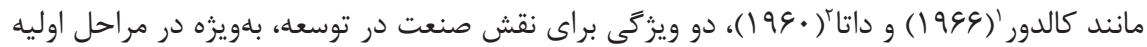
آن برمىشمارند: الف. سهمم صنعت در درآمدزايى براى كل اقتصاد در طول زمان (در فرايند توسعه) افزايش مى يابد؛ و ب. سهم نيروى كار بخش صنعت نيز در طول فرايند توسعه روندى صعودى دارد. تركيب اين دو ويزَى در طول فرايند توسعه موجب افزايش در آمد سرانه خواهد شد. حتى در مراحل نهايى توسعه نيز شاهد اين هستيم كه نوآورى و تلاش براى توسعه فناورىهاى دون جديد در در اغلب موارد

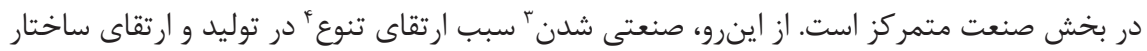
اقتصاد به سمت يِيجيدگى و افزايش بكاركيرى مهارت در توليد مىشود (Fajnzylber, 1983). در نتيجه، رشد صنعت يكى از راهكارهاى ايجاد درآمد، اشتغال، و توليد مهارت است. يروهشئها نشان

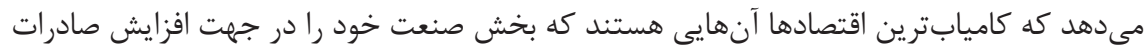

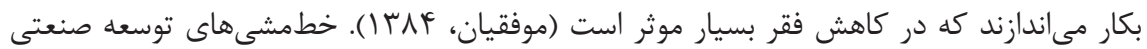

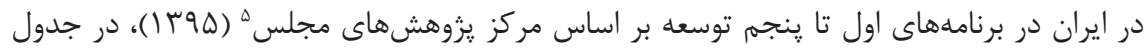

1. Kaldor

2. Datta

3. Industrialization 
جدول 1: خطمشىهاى توسعه صنعتى در ايران در برنامههاى توسعه اول تا ينجم

\begin{tabular}{|c|c|}
\hline خطمشى توسعه & برنامه توسعه \\
\hline 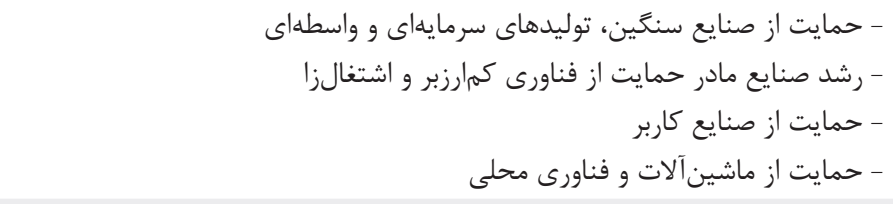 & اول \\
\hline 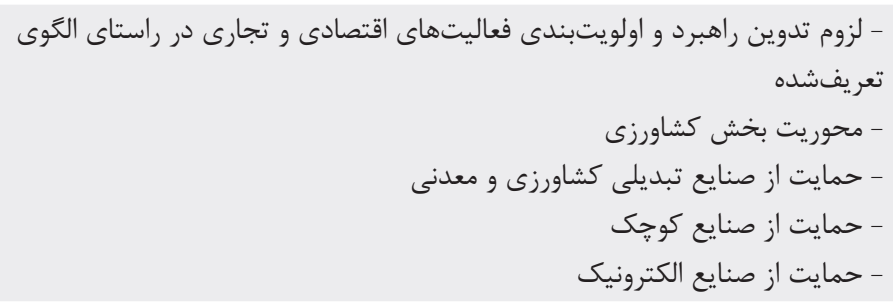 & دوم ل \\
\hline هماهنًَ) حمايت از توسعه صنايع الكترونيك (از راه سياستخذارى و سرمايهَذارى متمركز و & سوم \\
\hline 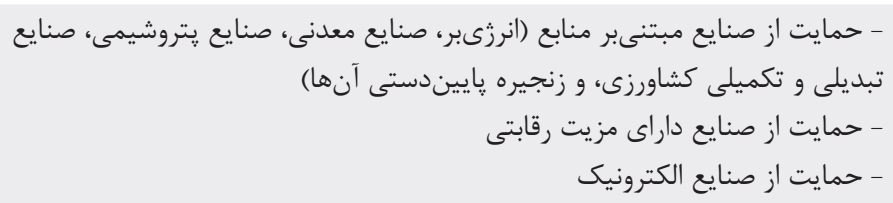 & جهارم \\
\hline 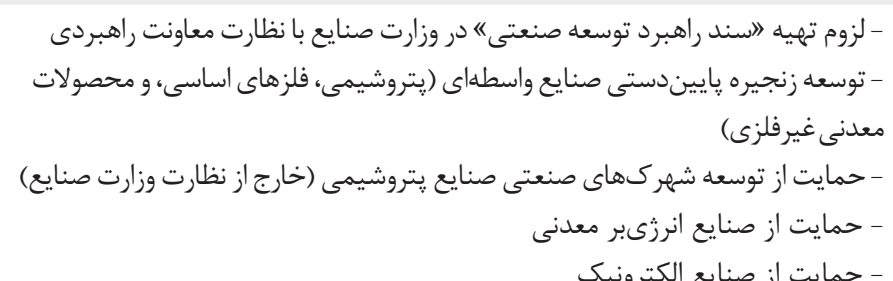 & ينجم \\
\hline
\end{tabular}

- حمايت از صنايع الكترونيك الردي معدن

منبع: مركز يثزوهش هاى مجلس هوبر

تلاش براى ارائه مفهومى تحليلى و كاربردى از رشد فقرزدا، به ارائه دو تعريف رشد فقرزداى نسبى و

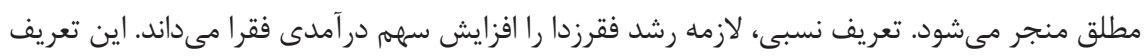
از دخالتهايى كه به كاهش نابرابرى منجر مىشوند، بدون توجه به اثر آنها بر رشد حمايت مى مند. از

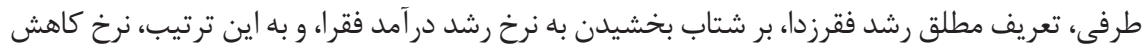

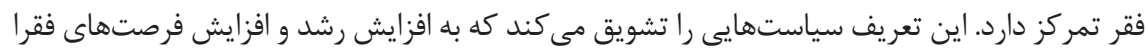




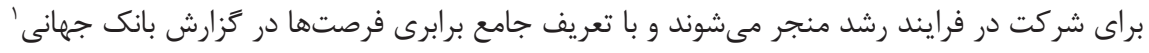

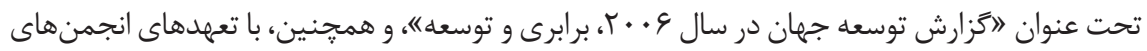

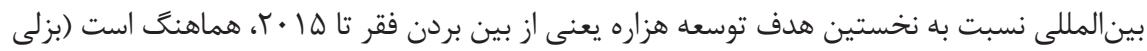

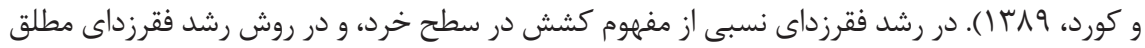
از الكوهاى كلانسنجى براى بررسى رابطه فقر با رشد استفاده مىشود. در خصوص اثر رشد اقتصادى و بخش صنعت بر كاهش فقر يروهشهايى در در سطوح بينالمللى و

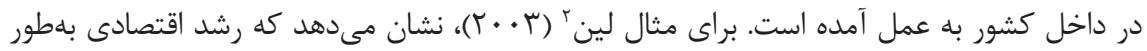

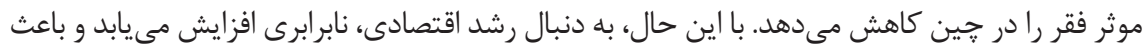

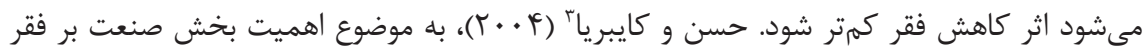

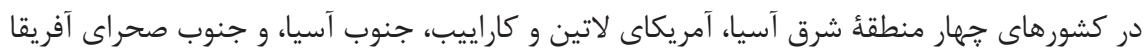
مى يردازند. نتايج يافتههاى آنها نشان مىدهد كه رشد مند صنعتى در هر منطقهاى اثر مثبتى بر كاهشي فقر دارد؛ در ضمن ييوند بين رشد صنعتى و كاهش فقر در شرق آسيا قوىتر از ساير مناطق است، به

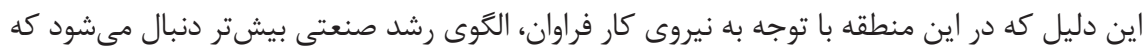

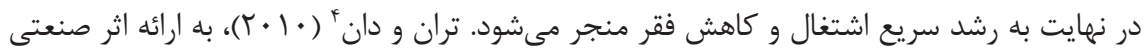

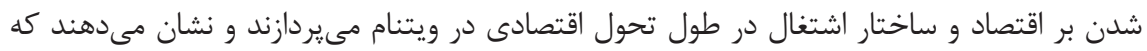

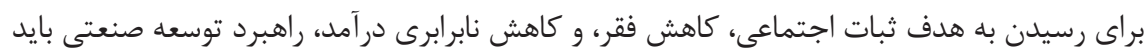

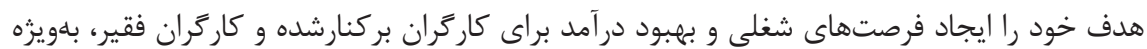

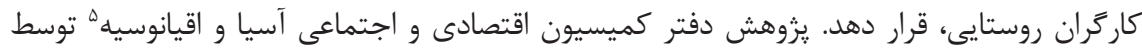

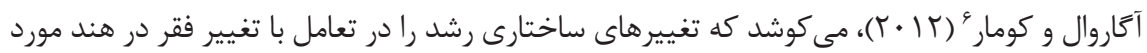
تجزيهوتحليل قرار دهد. اين يزوهش نشان مى دهد كه رشد اقتصادى در هند با تغييرهاى توزيعى در بين بخشهاى اقتصادى و به سمت بخشهايى با بهرهورى بالا همر اه است، و بر اساس اين، تفاوت كستردهاى

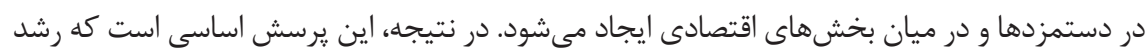

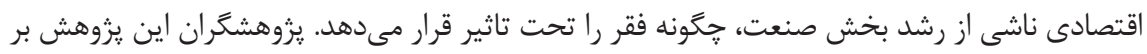

1. https://www.unido.org

2. Lin

3. Hasan \& Quibria

4. Tran \& Doan

5. Economic and Social Commission for Asia and the Pacific (ESCAP)

6. Aggarwal \& Kumar 
اين باور هستند كه رشد صنعتى تنها زمانى مىتواند فقر را كاهش دهد كه افراد فقير در فعاليتهاى

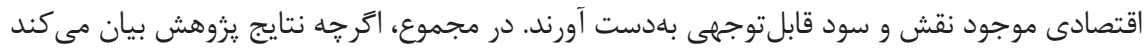
كه رشد صنايع توليدى هند فقر را كاهش مى مهدد اما همجنان جمعيت قابلملاحظهاى دركير فقر هستند. بنابراين، سياستهاى توزيع مجدد در جريان صنعتى شدن راهى برائ كاهش فيد فقر است. كيمورا

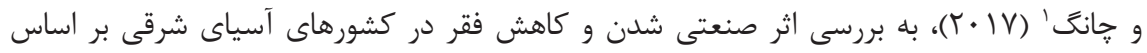
جنبش كاركرى داخلى مى يردازند. بر اساس اين يزوهش، آنجه باعث مى شود كه تعدادى از كشورهاى

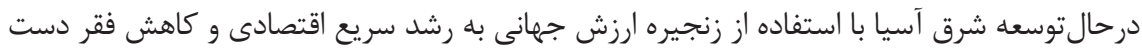

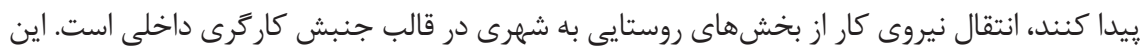

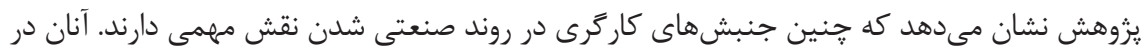
خصوص كشور تايلند نشان مى دهند كه جَّونه اين كشور مى تواند همزمان با رشد اقتصادى سريع، فقر را

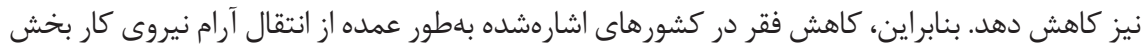

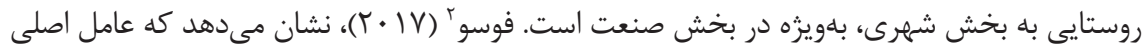

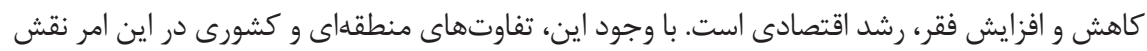

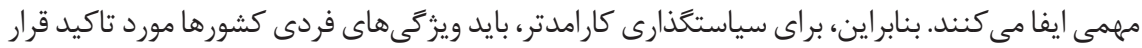

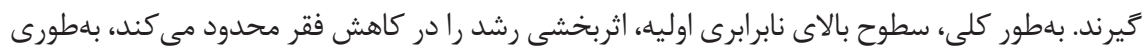

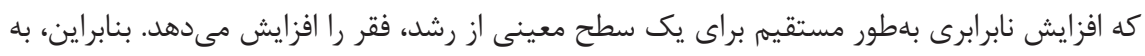

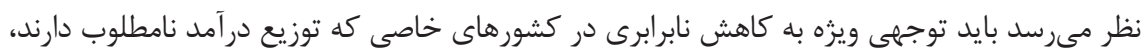

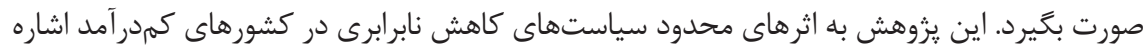

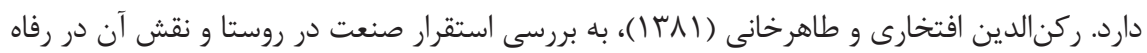

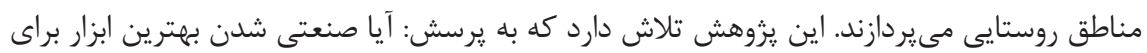
تحقق توسعه در مناطق روستايى در كشورهاى درحالتوسعه است؟، ياسخ دهد. با بررسى ينج اثر عمده

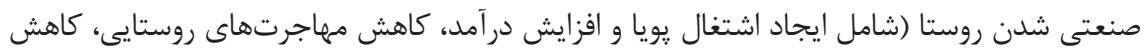

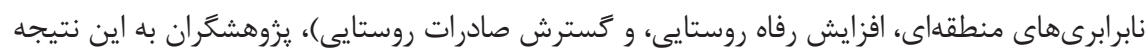

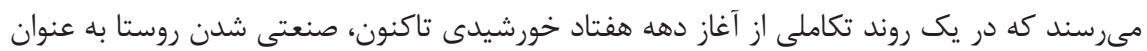
بخشى از راهبرد توسعه همهجانبه روستايى، مهمترين هدفهاى توسعه را در مناطق روستايى تحقق 
مىبخشد و ضمن ايجاد اشتغال و افزايش درآمد كروههاى كمدرآمد روستايى، موجب كاهش فقر و

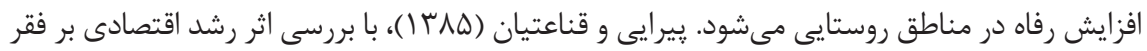

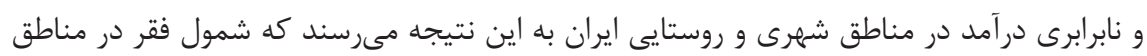
شهرى و روستايى ايران، كاهش، شدت، و عمق فقر را در مناطق روستايى افزايش ميىدهد. همجنين،

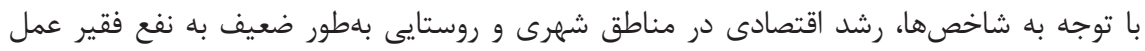
مى كند. صادقى و همكاران (1 (INV)، بيان مى كنند كه افزايش رشد توليد ناخالص داخلى باعث كاهش

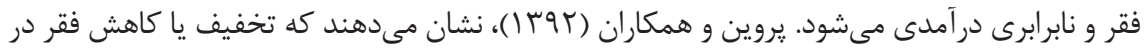

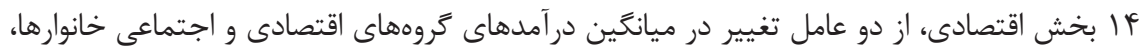

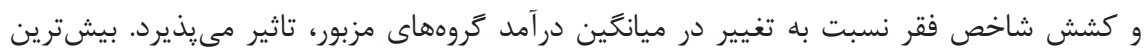

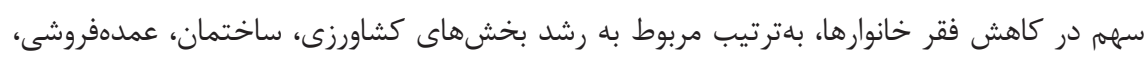
و خردهروشى است. همجنين، بخشهاى واسطه كرىهاى مالى و آموزش سهم قابل توجهى در كاهش

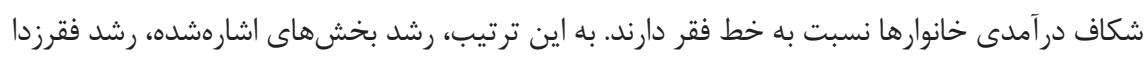

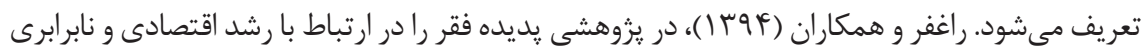

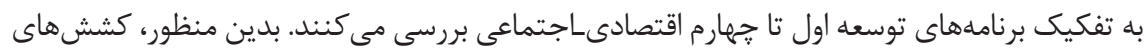

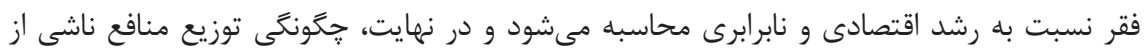

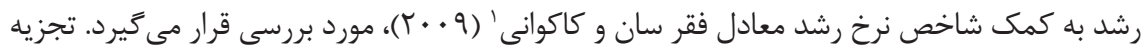

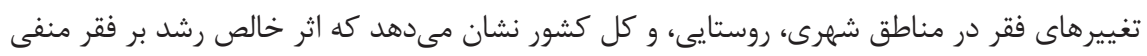
است، اما اثر خالص نابرابرى نوسانهاى مثبت و منفى دارد. تحولهاى اقتصادى و سياسى در در ايران تان

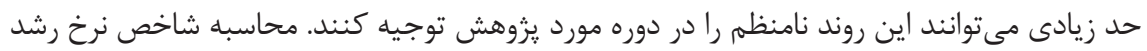

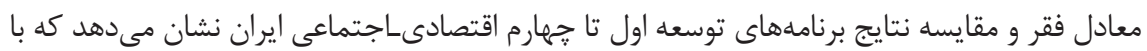

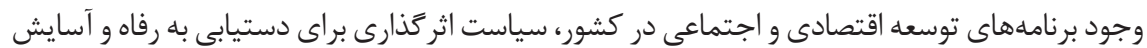
مستمر دنبال نمىشود. فيضيور و سامانيور (99 (1)، در يزوهشى تاثير توسعه صنعتى در مناطق ايران را

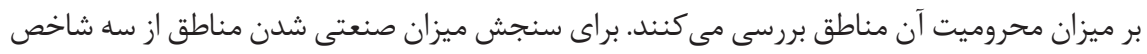

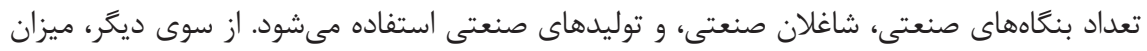

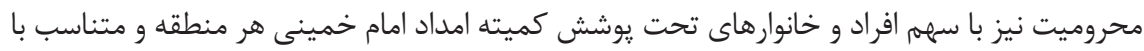
جمعيت آن مناطق ارزيابى مىشود. بر اساس نتايج اين يزوهش، توسعه صنعتى در مناطق جغرافيايى 
ايران زمينه كاهش محروميت رادر كاهش سهمم افراد و خانوارهاى مددجويان كميته امداد فراهم مى كند. از منظر سياستخذارى و بر اساس يافتههاى يزوهش، توجه به رشد متوازن بخش صنعت درئ در مناطق كشور، به منظور كاهش محروميت، امرى ضرورى است.

\section{تاثير رشد اقتصادى و نابر ابرى بر فقر}

طبق يزوهش كاكوانى' (سو9 ())، تغييرهاى متناسب در فقر مىتواند به اثر درآمد متوسط و اثر تغييرهاى نابرابرى تجزيه شود. وى از مفهوم كشش براى تجزيه عوامل موثر بر فقر استفاده ميى كند.

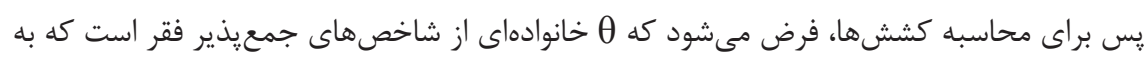
$\theta=\int_{0}^{z} P(z, x) f(x) d x$ صورت رابطه ( ) تعريف مى شود:

در رابطه ( )، درآمد هر فرد كه با x نشان داده مىشود، متغير تصادفى با تابع توزيع f(x) است.

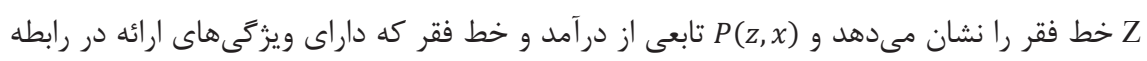

$\frac{\partial P}{\partial x}<0, \frac{\partial^{2} P}{\partial x^{2}} \geq 0, P(z, x)=0, P(z, x) x, z$ همخن از درجه صفر نسبت به

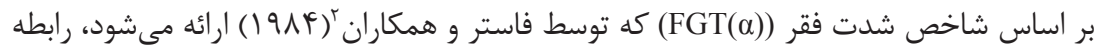

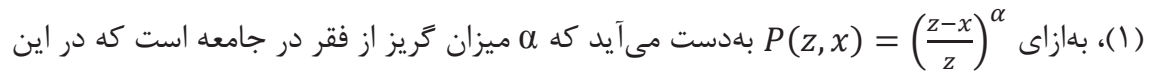
يزوهش d=2 لحاظ مىشود، كه نشاندهنده شدت عمق فقر است. همجنين،

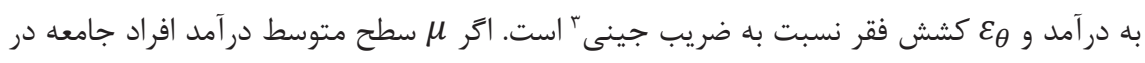

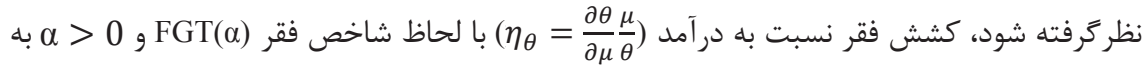
صورت رابطه (ب) بهدست مى آيد:

$\eta_{\alpha}=\frac{1}{\theta} \int_{0}^{Z} x \frac{\partial P}{\partial x} f(x) d x=-\frac{\alpha\left[\theta_{\alpha-1}-\theta_{\alpha}\right]}{\theta_{\alpha}}$ 
در رابطه (r)، با توجه به اين كه با افزايش d مقدار شاخص FGT كاهش مىيابد، كشش درآمدى

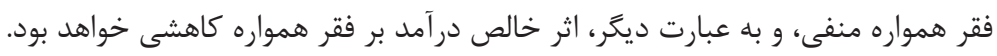

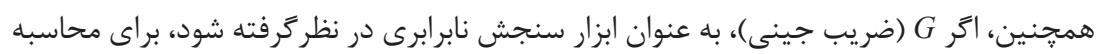

$$
\text { كشش فقر نسبت به نابرابرى }) \text { (ع) خواهيم داشت: }
$$

$$
\varepsilon_{\alpha}=\frac{1}{\theta} \int_{0}^{Z} \frac{\partial P}{\partial x}(x-\mu) f(x) d x=\eta_{\theta}-\frac{\mu}{\theta} \int_{0}^{Z} \frac{\partial P}{\partial x} f(x) d x=\frac{\alpha \theta_{\alpha-1}[\mu-z]+\alpha z \theta_{\alpha}}{z \theta_{\alpha}}
$$

از آنجايى كه عبارت [u-z -

باشد. به عبارت ديخر، افزايش نابرابرى به افزايش فقر منجر مى شىود.

\section{روشناسى يثروهش}

به منظور بررسى تاثير بخش صنعت بر كاهش فقر در استانهاى ايران، نخست بر اساس دادههاى

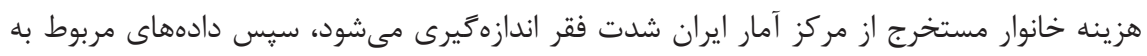
شاخص ضريب جينى و ارزشافزوده بخش صنعت براى فعاليتهاى صنعتى ده نفر كاركن و بيشتر در در

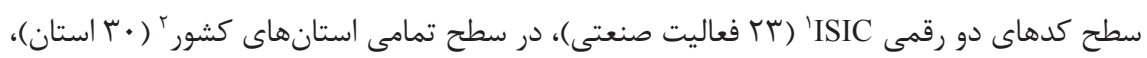

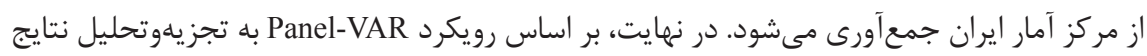
يرداخته مىشود. بنابراين، از روش توصيفى_تبيينى در اين يزوهش استفاده مىشود.

\section{اندازهَيرى فقر}

كام نخست در اندازمَيرى فقر، شناسايى فقر است و اين امر به وسيله خط فقر امكان يذير است. خط فقر

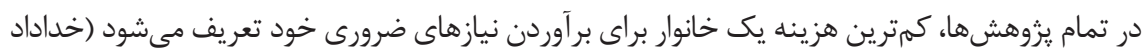

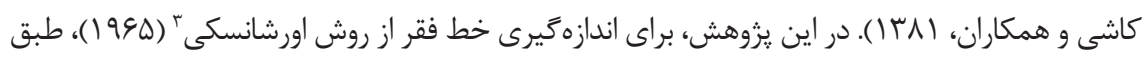

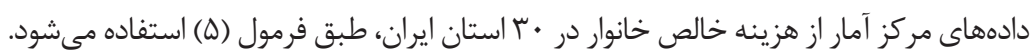
$z=A \frac{B}{C}$

1. International Standard Industrial Classification 
كه در آن، Z خط فقر، A خط فقر غذايى، B هزينه متوسط كل (خوراكى و غيرخوراكى)، و C متوسط هزينه خوراكى است. در اين يزوهش، افرادى زير خط فقر غذايى تعريف مىشوند كه قادر به فراهم نمودن نيازهاى مادى اساسى خود، بلويزه اولين نياز كه سلامت جسم و تغذيه مناسب است،

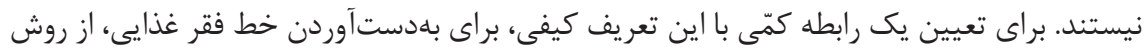

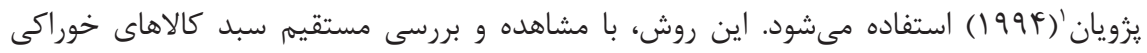

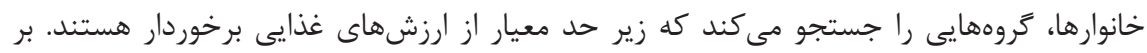
اساس نظر متخصصان تغذيهاى فرض مىشود كه هر فرد به ...r كالرى انرزى در روز نياز دارد،

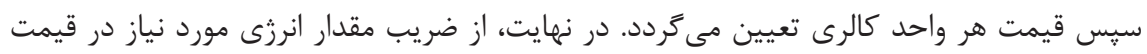

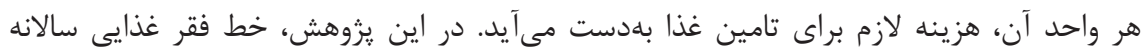

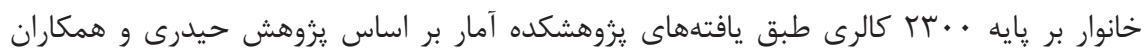

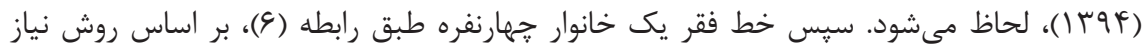

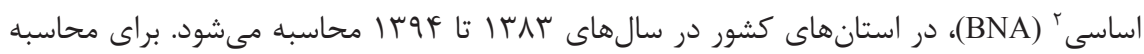

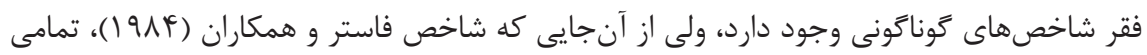

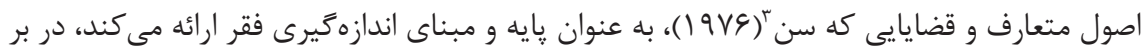
مى گيرد، به صورت (9) استفاده مىشود:

$F G T(\alpha)=\frac{1}{n} \sum_{i=1}^{q}\left[\frac{z-c_{i}}{z}\right]^{\alpha}$

در رابطه (9)، Z خط فقر خانوار، $C_{i}$ هزينه سرانه خانوار، n تعداد خانوار، $q$ تعداد خانوار زير خط

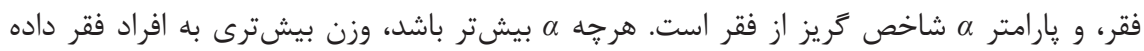
مىشود. دلايل استفاده از شاخص FGT(2) (شدت فقر)، در اين يزٔوهش از اين قرار است: ا. شاخص FGT(2) را مىتوان براى زير گروههاى روستايى و شهرى محاسبه كرد؛

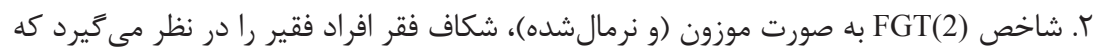
ضريب وزنى هر شكاف فقر همان شكاف فقر است. در نتيجه، ميزان محروميت هر فرد فقير تابعى از ميزان شكاف فقر اوست؛ و

1. Pajoyan

2. Basic-Needs Approach

3. Sen 


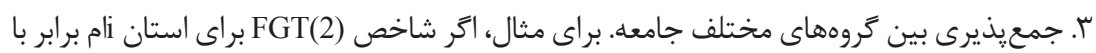

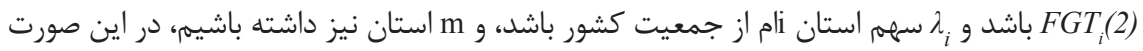

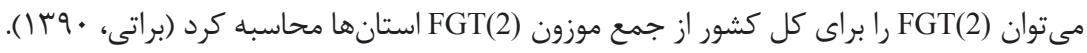

از آنجا كه ماهيت دادههاى يزوهش از نوع يانلى است، براى استخراج رابطه بين متغيرهاى

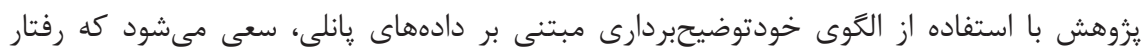

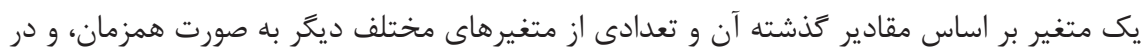
قالب دادهایى پانلى، توضيح داده شوند. در تحليل جندمتغيره دادههاى پانلى، بايد ارتباط درونى دادههاى تلفيقى بررسى شوند. وقتى تعداد متغيرهاى مدل بيش از دو باشد، ممكن است بيش از يك بردار هممانباشتكى بين متغيرها وجود داشته باشد. در اين شرايط، براى اينكه ارتباط تمامى متغيرها

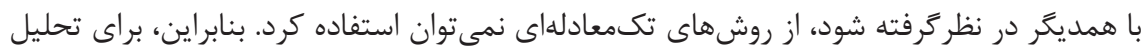
جندمتغيره دادهایى تابلويى، براى اين كه ارتباط تمامى متغيرها با همديكر در نظرگرفته شود، از

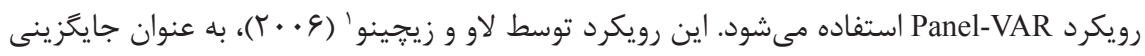
براى الكَهاى كلانسنجى معرفى مىشود. اين روش توانايى بيان ساختار يوياى مدل و توانايى حذف

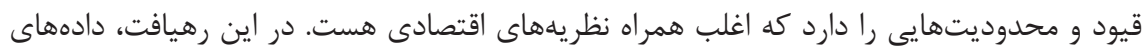

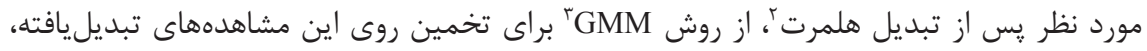

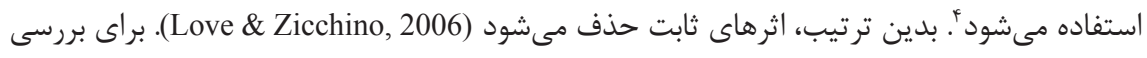

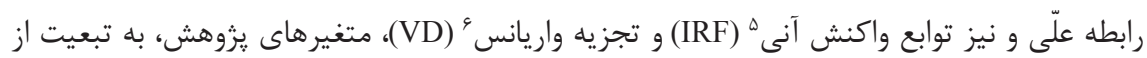

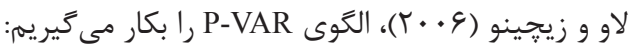

1. Love \& Zicchino

2. Helmert

3. Generalized Method of Moments

זُ. براى آزمون TNEss'Robu's لازم بود از روش Bayesian استفاده شود كه اين امر به يروهش بعدى موكول 


$$
\begin{aligned}
& L F G T_{i, t}=a_{10}+\sum_{j=1}^{p} b_{11} L F G T_{i, t-j}+\sum_{j=1}^{p} b_{12} L S V A I_{i, t-j}+\sum_{j=1}^{p} b_{13} L G i n i_{i, t-j}+(\vee) \\
& \mu_{i 0}+\varepsilon_{i 0, t} \\
& L S V A I_{i, t}=a_{20}+\sum_{j=1}^{p} b_{21} L F G T_{i, t-j}+\sum_{j=1}^{p} b_{22} L S V A I_{i, t-j}+\sum_{j=1}^{p} b_{23} L_{G i n i} i_{i, t-j}+(\wedge) \\
& \mu_{i 1}+\varepsilon_{i 1, t} \\
& \operatorname{LGini}_{i, t}=a_{30}+\sum_{j=1}^{p} b_{31} L F G T_{i, t-j}+\sum_{j=1}^{p} b_{32} L S V A I_{i, t-j}+\sum_{j=1}^{p} b_{33} L_{\text {Gini }} i_{i, t-j}+ \\
& \mu_{i 2}+\varepsilon_{i 2, t}
\end{aligned}
$$

كه در بردار هاى اشارهشده بالا، LSVAI LFGT، و LGini متغيرهاى وابسته سه كانه فقر، ارزشافزوده

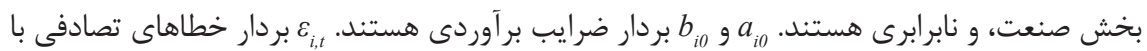
شرايط 0 بين مقاطع مختلف در بر مى سيرد.

\section{تجزيهوتحليل يافته ها}

براى تجزيهوتحليل دادهها از رويكرد Panel-VAR بر اساس روش تخمينى GMM از نرمافزار استاتا' نسخه له استفاده مىشود.

\section{نتايج شدت فقر در استانهاى ايران}

شاخص شدت فقر بيشترين وزن را به خانوارهايى مىدهد كه از خط فقر فاصله زيادترى دارند. يس هرجه فاصله خانوارها در جامعه از خط فقر افزايش يابد (توزيع درآمد ناعادلانهتر شود)، اين

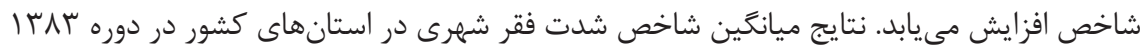

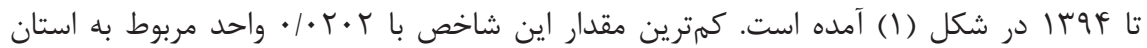
خوزستان و بيشترين ميزان آن با |\&9\&\• • واحد مربوط به استان سيستان و بلوجستان است.

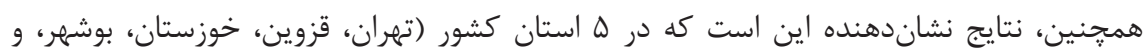

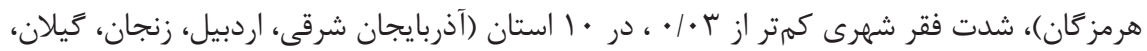

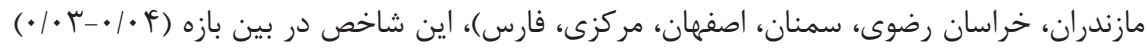

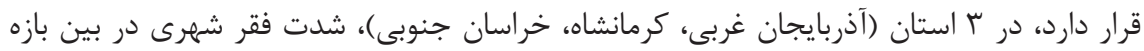




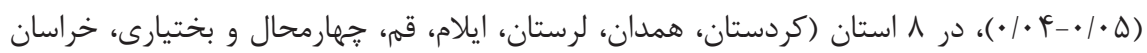

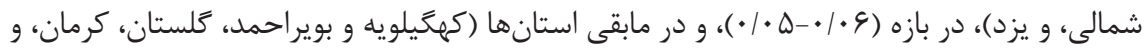

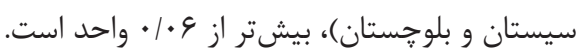

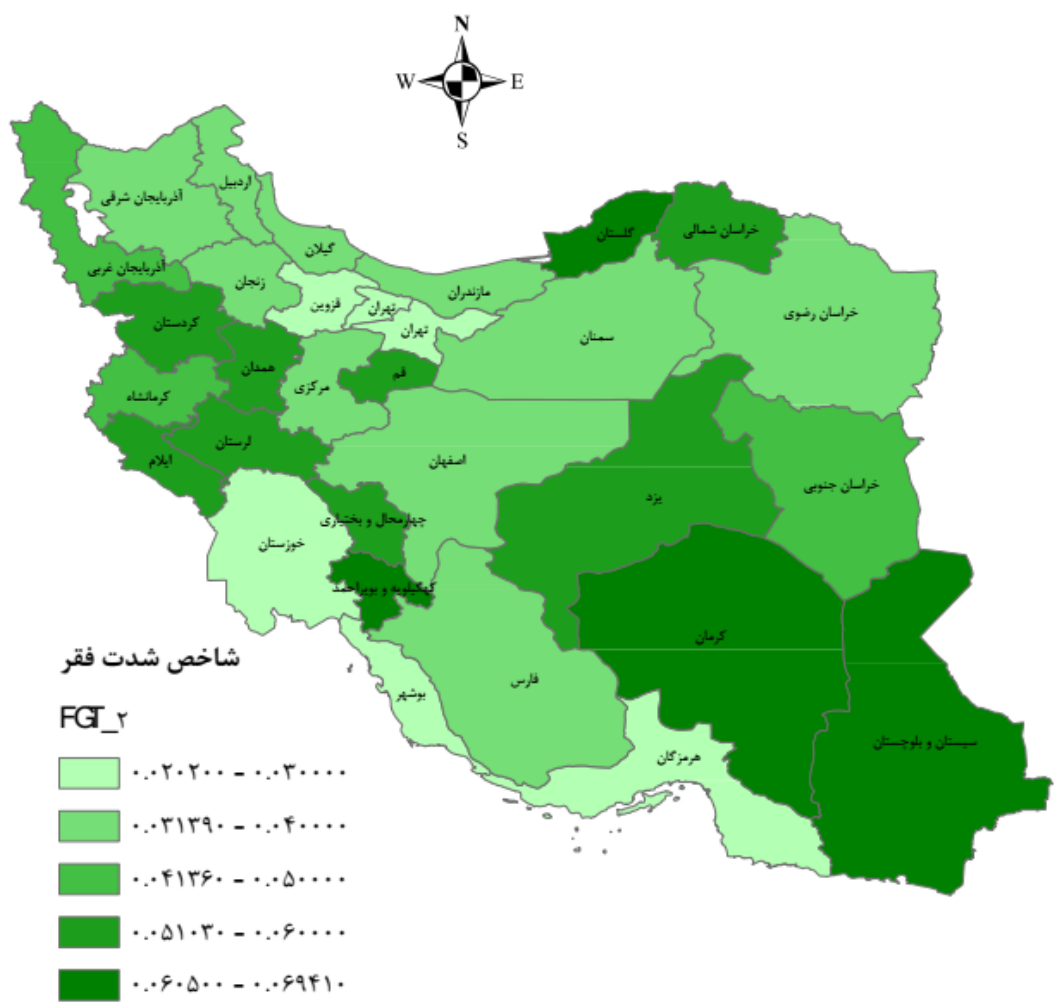

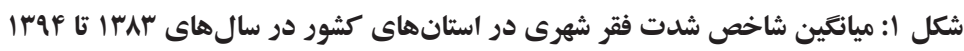

نتايج حاصل از بهرهورى كارگًاههاى صنعتى (ميليون ريال به كارگاه) ده نفر كاركن و بيشتر

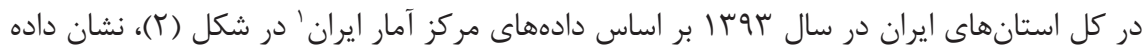

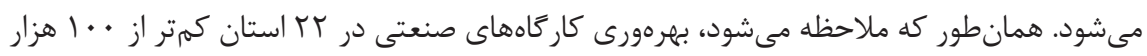


ميليون ريال، و ه استان در حدود · · ا هزار ميليون ريال است. از مقايسه نتايج حاصل از اندازهكيرى شدت فقر در شكل ( ()، با بهرهورى كار گاههاى صنعتى طبق شكل (؟)، در استانهاى كشور مى متوان بلهور ضمنى اظهار داشت كه استانهايى با بهرهورى كاركاههاى صنعتى بالا شدت فقر كمرى كمترى دارند.

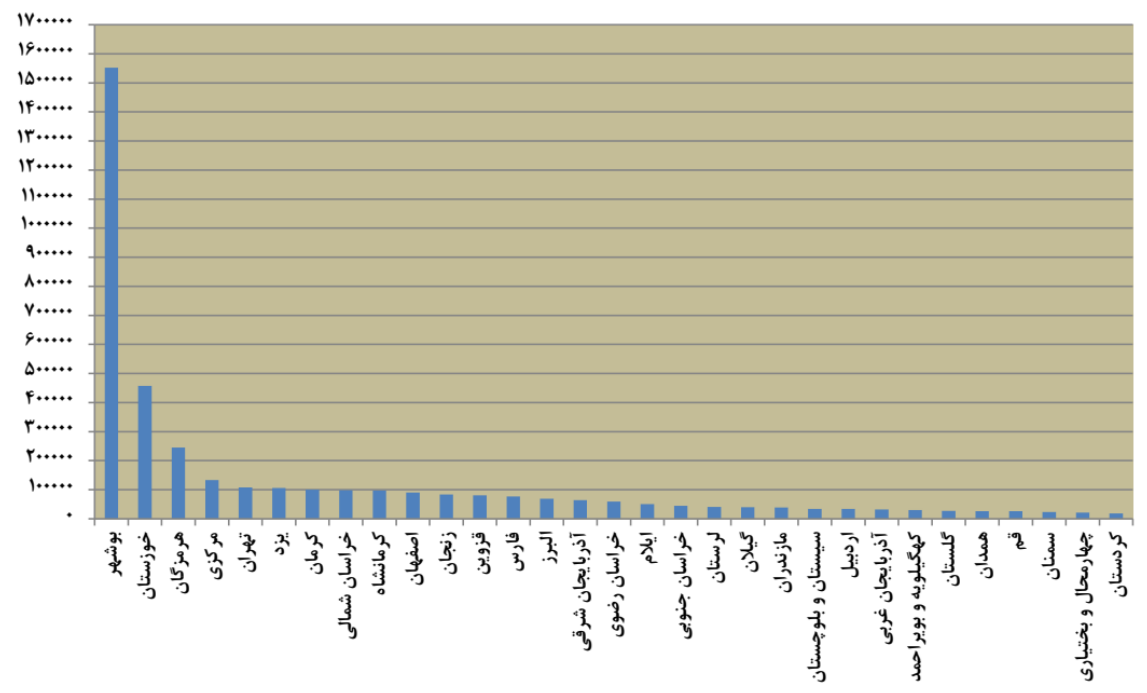

شكل rا: بهرهورى كار كاههاى صنعتى ده نفر كاركن و بيشتر برحسب ميليون ريال به كار كاه در سال آحسا (مر كز آمار ايران)

\section{Panel VAR نتايج رويكرد}

در اين بخش، براى بررسى تاثير بخش صنعت بر فقر در استانهاى كشور از رويكرد Panel-VAR

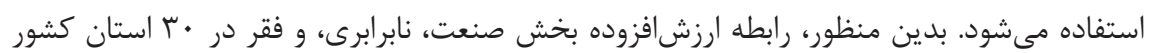
در r إل سال استفاده از روش P-VAR بررسى مىشود. نياز به اشاره است، در مدلهاى Panel-VAR،

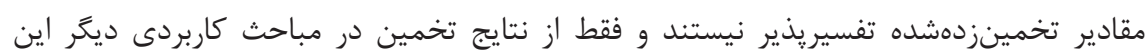

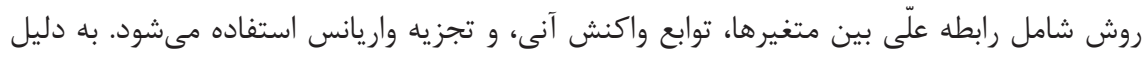

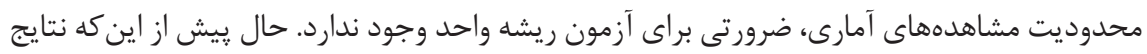

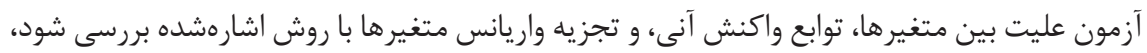

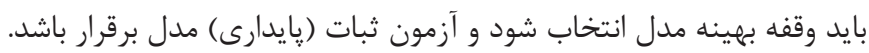




\section{وقفه بهينه مدلها}

از آنجايى كه روش Panel-VAR بر קايه انتخاب وقفه بهينه استوار است، بر اساس يزوهش اندرو و

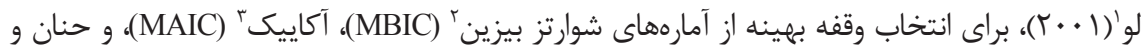
كويين" (MQIC) استفاده مىشود. با توجه به نتايج جدول (؟)، مقادير اين آمارهها در وقفه يك كمترين ميزان را دارند، پس وقفه يك به عنوان وقفه بهينه مدل انتخاب مىشود. نياز به توضيح است كه در وقفه يك، ضريب يب تعيين كلى (CD)، بر ابر با 99 / • است كه نشان مى دهد سهم تغييرهاى بيانشده توسط مدل بالاست.

جدول r: نتايج انتخاب وقفه بهينه مدل فقر، ارزشافزوده صنعت، و نابرابرى

\begin{tabular}{|c|c|c|c|c|}
\hline MQIC & MAIC & MBIC & CD & وقفه \\
\hline$-\varepsilon 1 / \cdot \forall \wedge \vee I$ & $-Y F / D I F V$ & 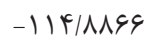 & . $/ 99 \Delta r G \Delta V$ & 1 \\
\hline$-r V / V \cdot r q 1$ & $-I r / K$ FVq & $-V r / \Delta 9 \Delta \wedge r$ & $\cdot / 99 \Delta ৭ \cdot \wedge \Delta$ & r \\
\hline -1N/g & $-\varepsilon / 4 q \cdot r \wedge q$ & & . /9q4\&VTV & $r$ \\
\hline
\end{tabular}

\section{آزمون ثبات (يايدارى) مدلها}

الكوى Panel-VAR داراى مدل VAR روى مقاطع است. همانند هر الخوى VAR بايد ثبات يا

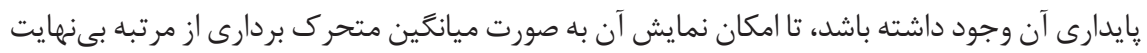

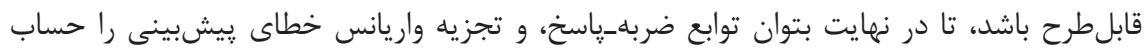

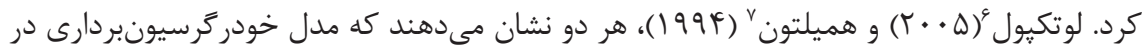

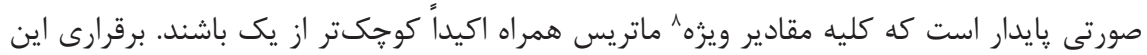
شرط (يايدارى)، متضمن معكوسيذير بودن مدل خودر گرسيونبردارى يانلى (PVAR) است. نتايج

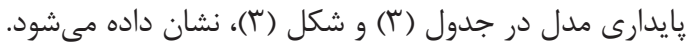

1. Andrews \& $\mathrm{Lu}$

2. MMSC-Bayesian Information Criterion

3. MMSC-Akaike Information Criterion

4. MMSC-Hannan \& Quinn Information Criterion

5. Overall Coefficient of Determination

6. Lütkepohl

7. Hamilton

8. Eigenvalue 
جدول "ז: نتايج آزمون پايدارى مدل فقر، ارزشافزوده صنعت، و نابرابرى

\begin{tabular}{|c|c|c|}
\hline \multicolumn{2}{|c|}{ مقادير ويزه } & \multirow{2}{*}{ قدر مطلق مقادير ويزه } \\
\hline مقدار موهومى & مقدار حقيقى & \\
\hline$\cdot$ & 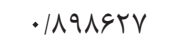 & - /А৭८૬५マ \\
\hline · & . MFATEV & - IFFATEV \\
\hline . & $-\cdot|r \cdot| \Lambda \cdot \Lambda \mid$ & $\cdot|r \cdot| \Lambda \cdot \Lambda \mid$ \\
\hline
\end{tabular}

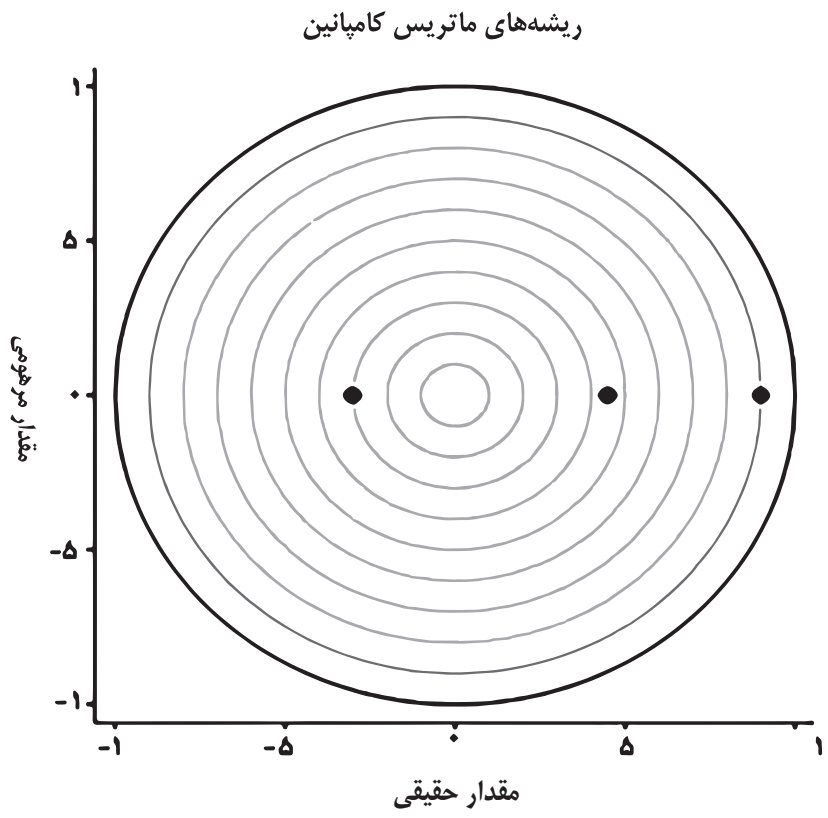

شكل rّ: آزمون ثبات (يايدارى) مدل فقر، ارزشافزوده صنعت، و نابر ابرى

با توجه به اين كه مقادير ويزه مدل كمتر از يك است و ريشه ماتريس كاميانين' در داخل دايره قرار مى گيرد، در نتيجه، شرط ثبات (يايدارى) در مدل Panel-VAR برقرار است. 


\section{نتايج آزمون عليت}

يكى از آزمونهاى بررسى رابطه عليت بين متغيرها، آزمون عليت گرنجرى' است. طبق اين

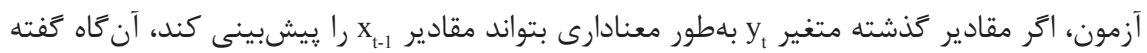
مى شود y علت گَرنجرى x است و بالعكس. اين آزمون نسبت به انتخاب طول وقفه بهينه حساس است و انتخاب نكردن طول وقفه مناسب و درست، موجب بروز مشكلات اغماضنايذير در مدل خواهد شد.

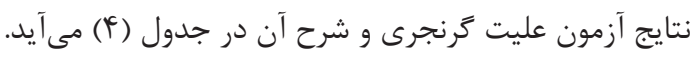

\section{جدول †: نتايج آزمون عليت كرنجرى بين متغيرها در مدل فقر، ارزشافزوده صنعت، و نابرابرى}

\begin{tabular}{|c|c|c|c|}
\hline نتيجه آزمون & احتمال & آماره خىدو & فرضيه صفر رابطه عليت \\
\hline نابرابرى عليت فقر است & .1 .99 & r/rAV & ضريب جينى عليت فقر نيست \\
\hline رشد صنعت عليت فقر است & $\cdot / \cdots$ & IN/VTA & ارزشافزوده صنعت عليت فقر نيست \\
\hline نابرابرى و رشد صنعت عليت فقر است & $\cdot / \cdots$ & Fr/fVG & نابرابرى و رشد صنعت عليت فقر نيست \\
\hline فقر عليت نابرابرى است & $.1 \cdot 14$ & $s / \mu \cdots$ & فقر عليت نابرابرى نيست \\
\hline رشد صنعت عليت نابر ابرى است & $\cdot / \cdots$ & $19 / 0 F 9$ & ارزشافزوده صنعت عليت نابرابرى نيست \\
\hline فقر و رشد صنعت عليت نابرابرى است & $\cdot / \cdots$ & ।घ/9६र & فقر و رشد صنعت عليت نابرابرى نيست \\
\hline فقر عليت رشد صنعت نيست & ./VGV & $\cdot / \cdot \wedge V$ & فقر عليت ارزشافزوده صنعت نيست \\
\hline نابرابرى عليت رشد صنعت نيست & • MGT & . IAtr & نابرابرى عليت ارزشافزوده صنعت نيست \\
\hline فقر و نابرابرى عليت رشد صنعت نيست & $\cdot 19 \Delta V$ & ./Arq & فقر و نابرابرى عليت رشد صنعت نيست \\
\hline
\end{tabular}

نتايج آزمونهاى عليت گرنجرى نشانگر اين واقعيت است كه بين ارزشافزوده بخش صنعت و فقر عليت گرنجرى يكىطرفه وجود دارد، بهطورى كه رشد بخش صنعت عليت فقر است، ولى فقر

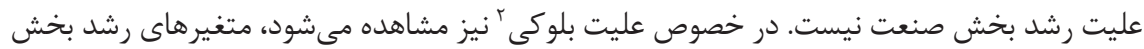
صنعت و نابر ابرى (ضريب جينى)، عليت فقر هستند، ولى فقر و نابرابرى عليت بخش صنعت نيستند. اين نتيجه، نشاندهنده اين امر است كه رشد صنعت در حضور نابرابرى نيز توضيحدهنده تغييرهاى شدت فقر شهرى در استانهاى كشور است؛ ولى شدت فقر در حضور نابرابرى توضيحدهنده تغييرهاى بخش صنعت نيست. نتايج عليت دومتغيره و بلوكى همراستاست. 


\section{نتايج توابع واكنش آنى}

يكى از كاربردهاى مدل P-VAR، بررسى واكنش متغيرهاى الكًو نسبت به شوكهاى بهوجودآمده

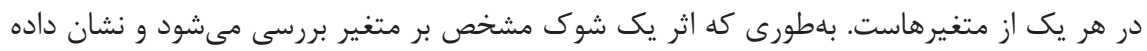
مىشود كه اگر يك تغيير ناگمهانى (شوك)، در يك متغير رخ دهد، اثر آن روى خود متغير و ديگر متغيرها در طول دورههاى مختلف جه مقدار خواهد بود. در بخش مبانى نظرى يزوهش، ارتباط بلندمدت متغيرها تبيين شدند. در تفسير توابع واكنش آنى نمىتوان به ارتباطهاى اشارهشده رجوع كرد، زيرا توابع واكنش آنى، رفتار متغيرهاى سيستم را در كوتاهمدت نشان مى دهند، و در محاسبه

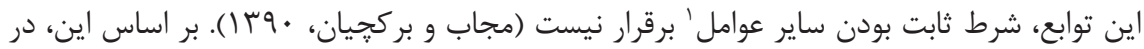
تحليل نتايج بهدستآمده از اين توابع، تنها در قالب فرضيههايى به بررسى نتايج يرداخته مىشود.

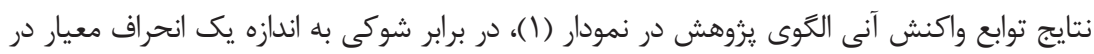
ارزشافزوده فعاليتهاى صنعتى سرانه، ضريب جينى، و شدت فقر در دوره ها اله ساله نشان داده مىشود. طبق اين نمودار، سطرهاى اول تا سوم بلترتيب نشاندهنده شوكهاى متغيرهاى للاريتم ضريب جينى، لخاريتم ارزشافزوده سرانه صنعت، و لماريتم شاخص شدت فقر بر خود متغيرها و نيز ساير متغيرهاست. به عبارت ديغر، سطر ها نشان دهنده اثر يك شوك بر سه متغير، و ستونهانشانكر اثرهاى سه شوك بر يكى متغير هستند.
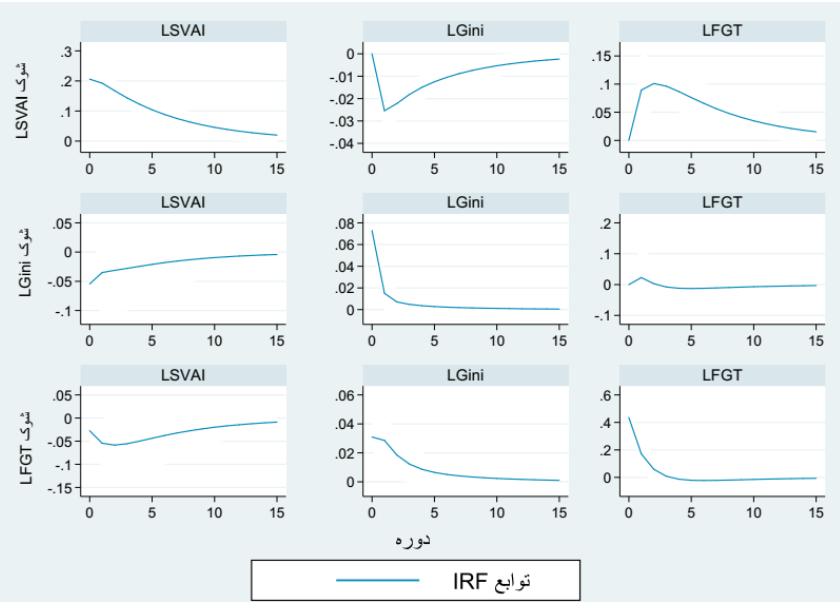

نمودار ا: توابع واكنش آنى متغيرها در مدل فقر، ارزشافزوده صنعت، و نابرابرى

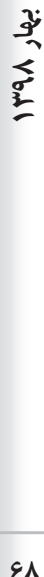

1. Ceteris Paribus 
بررسى نمودارها حاكى از آن است كه تمامى نمودارها به سمت صفر ميرا هستند و يس از مدتى،

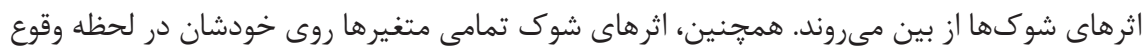

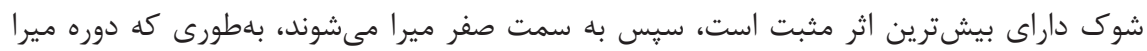

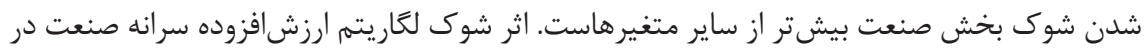
لحظه وقوع بر شاخص شدت فقر شهرى در استانهاى ايران صفر است. در دورههاى بعدى، اثرهاى شوك كمتر مىشود و به صفر ميل مى كند. اين نتيجه، بيانكر اين است كه تاثيرهاى بخش صنس صنعت بر بر

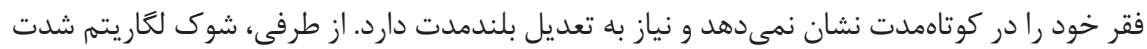

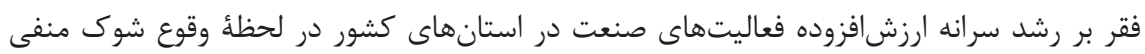
است. در دورههاى بعدى، اثرهاى شوى به صفر ميرا مىشود. جنانجه انتظار مىرفت، شوكى فقر در

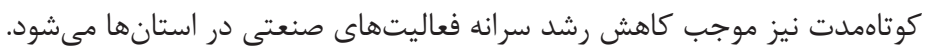

\section{نتايج تجزيه واريانس}

تجزيه واريانس ابزار ديگر رويكرد Panel-VAR است كه به بررسى عملكرد يويايى مدل مى يردازد.

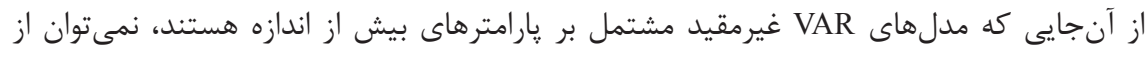

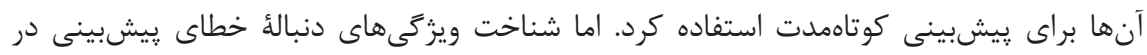
كشف روابط متقابل ميان متغيرهاى سيستم بسيار موثر خواهد بود. فرض كنيد مقدار ضرايب مشخص هستند و هدف يِيشبينى مقادير مختلف X اين صورت، خطاى ييشبينى در حالت كلى به صورت رابطه ( • (1) بهدست مى مد آيد: $X_{t+n}=\alpha+\sum_{i=0}^{\infty} \varphi_{i} \varepsilon_{t+n-i}$

$$
X_{t+n}-E_{t} X_{t+n}=\alpha+\sum_{i=0}^{n-1} \varphi_{i} \varepsilon_{t+n-i}
$$

يس خطاى پيشبينى n دوره بعد، عبارت خواهد بود از:

با تجزيه واريانس خطاى ييشبينى مىتوان بررسى كرد كه تغييرهاى يك دنباله تا جه حد

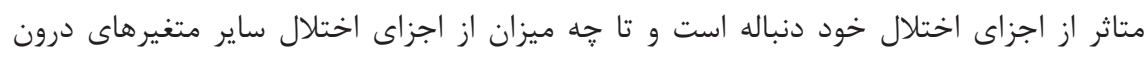
سيستم اثر مى يذيرد. بنابراين در روش تجزيه واريانس، سهم شوكهاى واردشده بر متغيرهاى

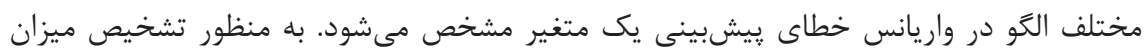


اهميت متغيرها در توضيحدهندگى نوسانهاى يك متغير، تجزيه واريانس متغيرها مورد بررسى

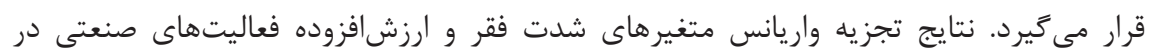

$$
\text { جدول (ه) و (ब) مى آيد. }
$$

جدول ه: نتايج تجزيه واريانس متغير لكاريتم شدت فقر

\begin{tabular}{|c|c|c|c|}
\hline لكَاريتم ارزشافزوده & & & لكَاريتم شدت فقر \\
\hline سرانه صنعت & ضريب جينى & شدت فقر & دوره \\
\hline . & $\cdot$ & 1 & 1 \\
\hline 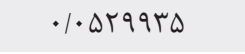 & $.1 . .94 .91$ & $\cdot / 9 r \cdot r \cdot . r$ & r \\
\hline.$/ 1 \Delta 91 \& \vee \Delta$ & $\cdot / \cdot$ VVGG & . MNT.GGT & $\Delta$ \\
\hline .1191 .909 & $.1 \cdot 1111 \mathrm{~F}$ & - NQVVVGAT & 1. \\
\hline.$/ 19 Y \wedge V V I$ & $.1 .11 k 9 \Delta F$ & - /VQDGFVF & 10 \\
\hline ./19Y१दTऽ & $\cdot 1 \cdot 110191$ & $\cdot / V 9 \Delta \Delta T \cdot F$ & $r$. \\
\hline . /19イ९९Vद & $. / \cdot 1101 V \mid$ & 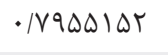 & $r$. \\
\hline . /19Y9\&Vद & $\cdot / \cdot 1101 V 1$ & 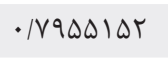 & r. \\
\hline ./19Y9\&Vद & $.1 .1101 V 1$ & 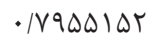 & $\Delta \cdot$ \\
\hline
\end{tabular}

جدول و: نتايج تجزيه واريانس متغير لكاريتم ارزشافزوده فعاليتهاى صنعتى سرانه

\begin{tabular}{|c|c|c|c|}
\hline \multirow{2}{*}{ سرانه صنزون } & \multirow[t]{2}{*}{ ضريب جينى } & \multirow[t]{2}{*}{ شدت فقر } & \multirow{2}{*}{ متغير وابسته ارزشافزوده } \\
\hline & & & \\
\hline . & . 1 va्qq91 & $\cdot|\cdot| r \mid 9 \Lambda$ & 1 \\
\hline$\cdot \mid \wedge \vee \cdots \wedge \wedge$ & $.1 .9194 V \Delta$ & .1. GVagtr & r \\
\hline - IVADFATR & $.1 .9 Y \Delta \Delta 91$ & $\cdot / 1019 \vee \vee \wedge$ & $\Delta$ \\
\hline$\cdot / V \Delta V \wedge / 9 \Delta$ &.$/ . \varepsilon r \vee \wedge r I$ & - /IVArqur & 1. \\
\hline$\cdot / V \Delta \Delta \Lambda \Lambda \cdot r$ & $.1 \cdot G \mathrm{MNVDQ}$ & - MN. TFTA & 10 \\
\hline$\cdot / V \Delta \Delta V \nabla V I$ &.$/ .9 r \wedge \Lambda 1$ & $\cdot / 11 \cdot r<19$ & $r \cdot$ \\
\hline$\cdot / V \Delta \Delta V V I 9$ &.$/ .9 M N A I T$ & $\cdot / 1 \Lambda \cdot r F \& \Lambda$ & r. \\
\hline$\cdot / V \Delta \Delta V V I 9$ &.$/ .9 r N A I r$ & $\cdot / \mid \Lambda \cdot r F \& \Lambda$ & f. \\
\hline$\cdot / V \Delta \Delta V V I 9$ & . & $\cdot / \Lambda \cdot r F \& \Lambda$ & $\Delta \cdot$ \\
\hline
\end{tabular}


تجزيه واريانس متغير شدت فقر نشان مى دهد كه در دوره دوم، \& متغير و / ه درصد تغييرها مربوط به ارزشافزوده سرانه صنعت است. با افزايش تعداد دورهها مشاهده

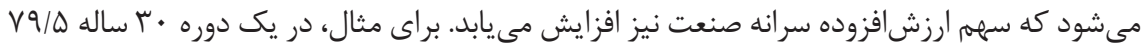
درصد تغييرها مربوط به خود متغير و 19/ ا درصد مربوط به ارزشافزوده فعاليتهاى صنعتى سرانه

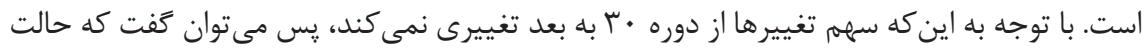

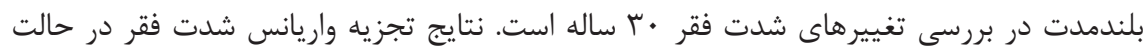
بلندمدت گوياى اين واقعيت است كه حدود • ^ درصد تغييرهاى شدت فقر مربوط به خود متغير و حدود 9 درصد تغييرها مربوط به ارزشافزوده بخش صنعت است. تجزيه واريانس متغير ارزشافزوده سرانه صنعت نشان مى دهد كه دوره اول، همه متغيرها در توضيحدهندگى متغير وابسته نقش دارند.

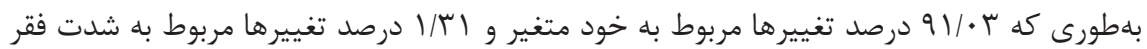

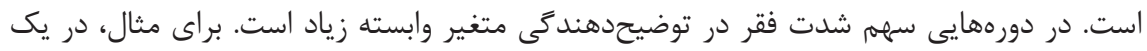

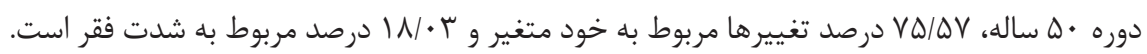

\section{بحث و نتيجه}

با توجه به اهميت كاهش فقر در سياستخذارى اقتصادى، توجه به راهبردهاى مختلف در اين

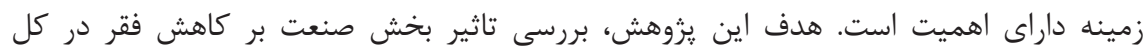

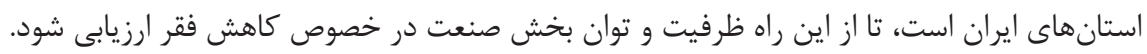

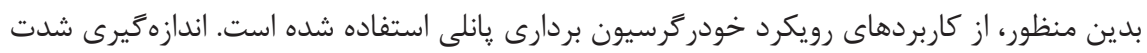

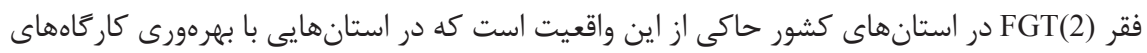

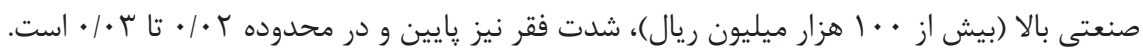
نتايج رويكرد Panel-VAR براى بررسى اثرهاى بخش صنعت بر فقر در استانهاى كشور بدين قرار

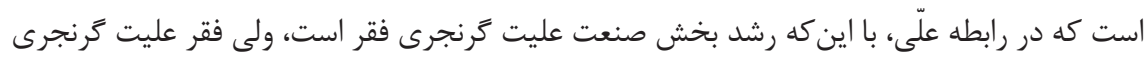

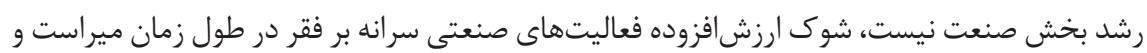
به صفر ميل مى كند، ولى در لحظةٌ وقوع شوك، اثرى بر شدت فقر ندارد، و اين كه طبق تجزيه واريانس ارزشافزوده فعاليتهاى صنعتى سرانه بيشتر از شاخص ضريب جينى، تغييرهاى شدت فقر رات را توضيح

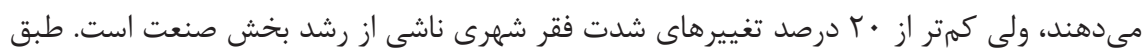

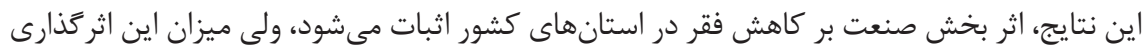


اندك است. در مورد دلايل اين اثركذارى اندك، توجه به ويزگى هاى فعاليتهاى صنعتى در سطح

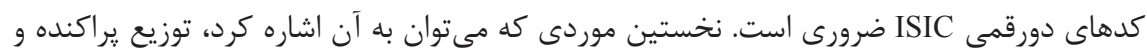

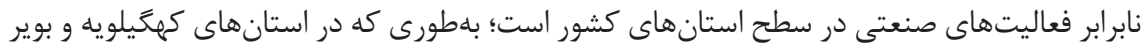
احمد، ايلام، و جهارمحال و بختيارى سه فعاليت صنعتى، و استان سيستان و بلوجستان ينج فعاليت صنعتى با ده نفر كاركن و بيشتر در سطح كدهاى دورقمى فعال هستند. دومين مورد، يراكندگى زياد شاخص نسبت تعداد اشتغال به تعداد كاركاههاى صنعتى در استانهاى كشور است؛ بهطورى كه

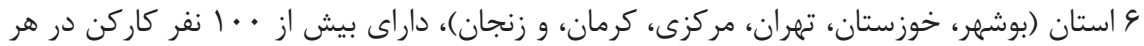

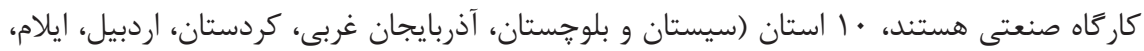

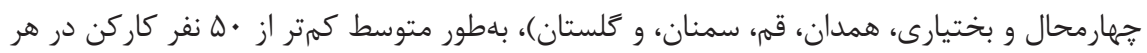

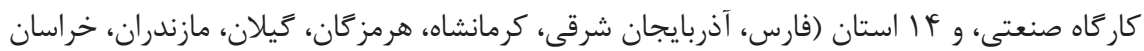

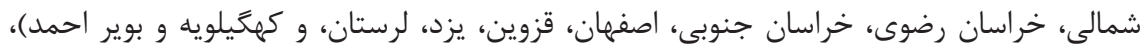

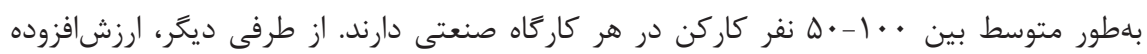
فعاليتهاى صنعتى در سطح كدهاى دورقمى بسيار متفاوت است، بهطورى كه صنايع شيميايى،

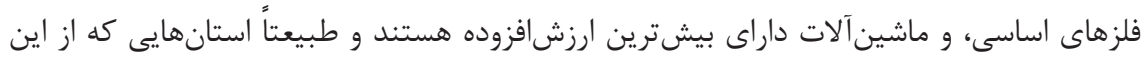

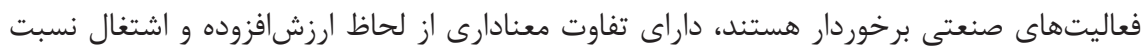

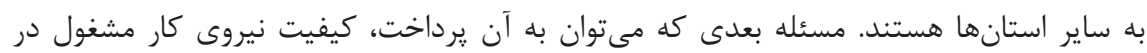

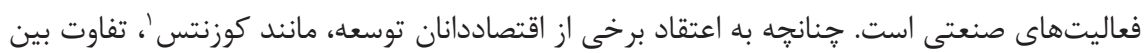

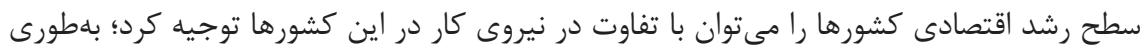

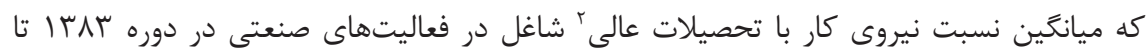

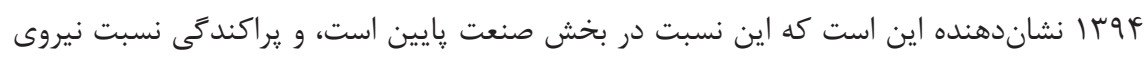

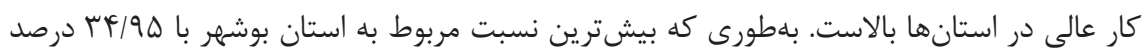

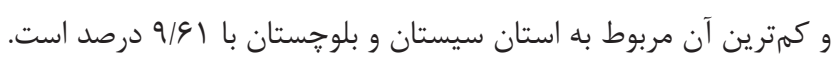

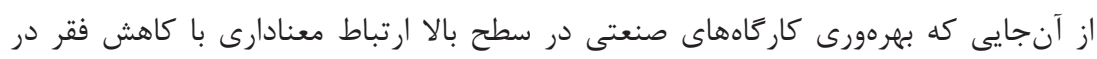

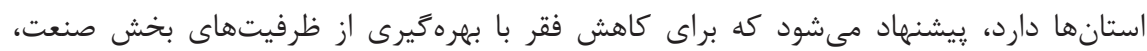
توجهى ويره به اين بخش شود. جنانجه در بند (1) سياستهاى كلى نظام در بخش صنعت، به

\section{Kuznets}

ז. منظور از تحصيلات عالى، تحصيلات دانشگاهى فوق دييلم، كارشناسى، كارشناسى ارشد، و دكترى است. 
افزايش سهمم بخش صنعت در توليد ناخالص داخلى و افزايش ارزشافزوده بخش صنعت، با دستيابى به رشد مطلوب سرمايه گذارى صنعتى، انتخاب فرايندهاى صنعتى دانشمحور، و ارتقاى منزلت كار،

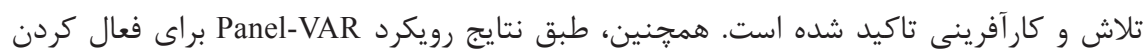

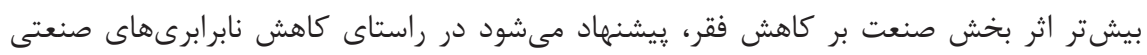

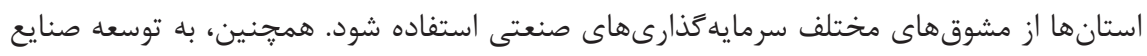

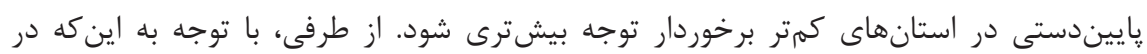

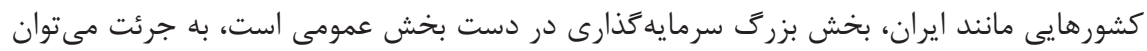

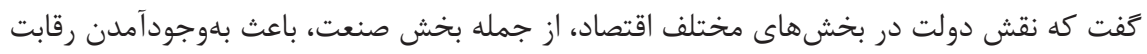

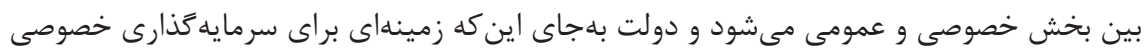

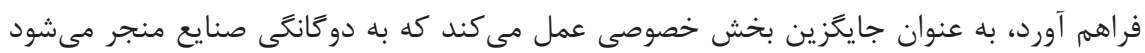

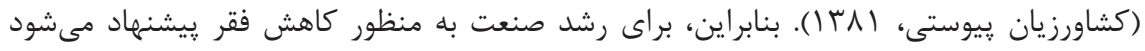

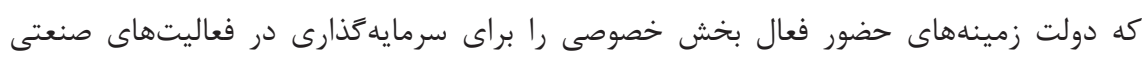
فراهم كند.

\section{منابع}

احمدى، علىمحمد، و شقاقى شهرى، وحيد (IVIV) (IV). توسعه /قتصادى و برنامهريزى. انتشارات نور علم.

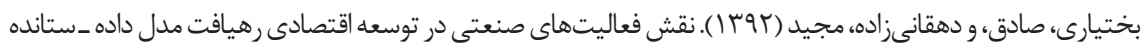

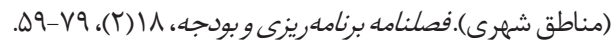

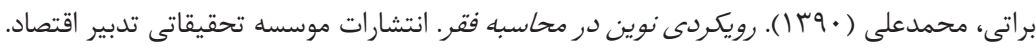

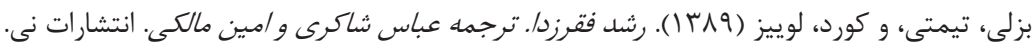

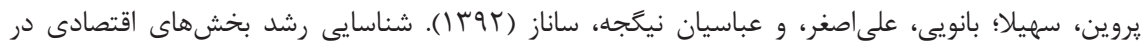

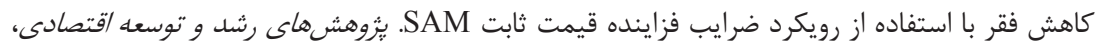

$r V-Y \cdot(1 \cdot) r$

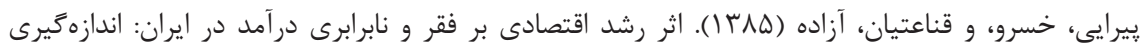

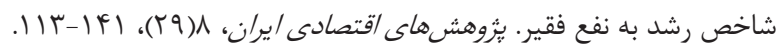

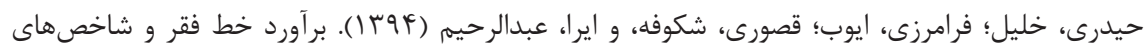




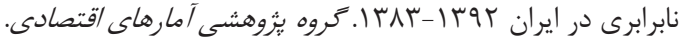

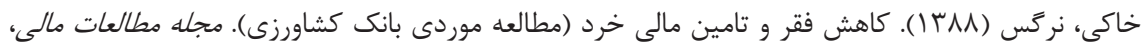

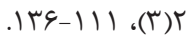

$$
\begin{aligned}
& \text { خداداد كاشى، فرهاد؛ باقرى، فريده؛ حيدرى، خليل، و خداداد كاشى، اميد (1) (1). اندازهكيرى }
\end{aligned}
$$

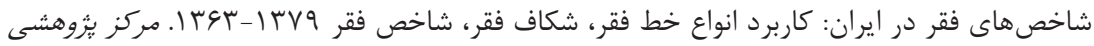

$$
\begin{aligned}
& \text { آمار اقتصادى. }
\end{aligned}
$$

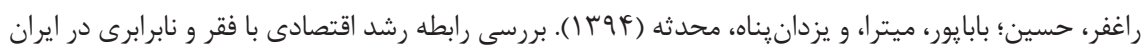

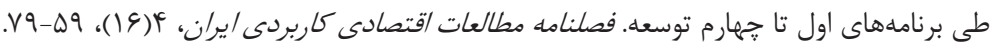

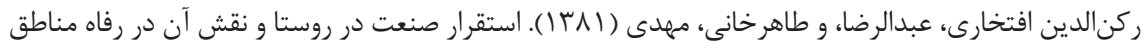

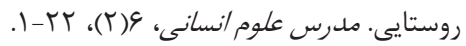

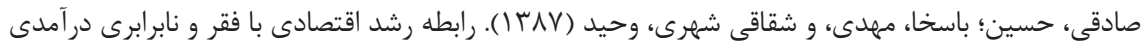

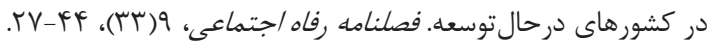

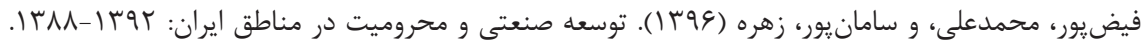

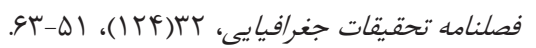

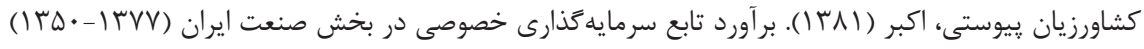

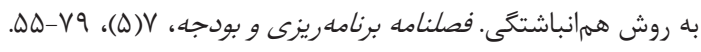

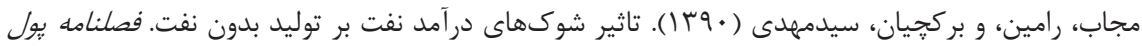

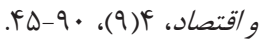

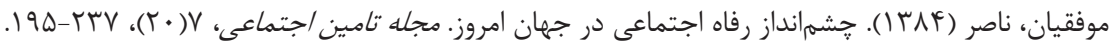

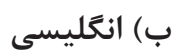

Aggarwal, A., \& Kumar, N. (2012). Structural Change, Industrialization, and Poverty Reduction: The Case of India, South and South-West Asia Development Papers 1206.

Andrews, D. W., \& Lu, B. (2001). Consistent Model and Moment Selection Procedures for GMM Estimation with Application to Dynamic Panel Data Models. Journal of Econometrics, 101(1), 123-164.

Datta, B. (1960). The Economics of Industrialization: World Press.

Fajnzylber, F. (1983). La industrialización trunca de América Latina: Editorial Nueva Imagen.

Foster, J., Greer, J., \& Thorbecke, E. (1984). A Class of Decomposable Poverty Measures. Econometrica: Journal of the Econometric Society, 52(3), 761-766.

Fosu, A. K. (2017). Growth, Inequality, and Poverty Reduction in Developing Countries:

Recent Global Evidence. Research in Economics, 71(2), 306-336. 
Hamilton, J. D. (1994). Time Series Analysis (Vol. 2): Princeton New Jersey.

Hasan, R., \& Quibria, M. G. (2004). Industry Matters for Poverty: A Critique of Agricultural Fundamentalism. Kyklos, 57(2), 253-264.

Kakwani, N. (1993). Poverty and Economic Growth with Application to Côte d'Ivoire. Review of Income and Wealth, 39(2), 121-139.

Kaldor, N. (1966). Causes of the Slow Rate of Economic Growth of the United Kingdom: An Inaugural Lecture: Cambridge University Press.

Khan, M. H. (2015). Supporting Inclusive Growth, Effective Policy Design for Developing Medium Technology Sectors: Application to Vietnam.

Kimura, F., \& Chang, M. S. (2017). Industrialization and Poverty Reduction in East Asia: Internal Labor Movements Matter. Journal of Asian Economics, 48(1), 23-37.

Lin, B. Q. (2003). Economic Growth, Income Inequality, and Poverty Reduction in People's Republic of China. Asian Development Review, 20(2), 105-124.

Love, I., \& Zicchino, L. (2006). Financial Development and Dynamic Investment Behavior: Evidence from Panel VAR. The Quarterly Review of Economics and Finance, 46(2), 190-210.

Lütkepohl, H. (2005). New Introduction to Multiple Time Series Analysis: Springer Science \& Business Media.

Orshansky, M. (1965). Counting the Poor: Another Look at the Poverty Profile. Social Security Bulletin, 28(1), 3-32

Pajooyan, J. (1994). A Method for Establishing a Support Criterion or Poverty Line. Iranian Economic Review, 1(1), 44-57.

Sen, A. (1976). Poverty: An Ordinal Approach to Measurement. Econometrica: Journal of the Econometric Society, 44(2), 219-231.

Son, H. H., \& Kakwani, N. (2009). Measuring the Impact of Price Changes on Poverty. The Journal of Economic Inequality, 7(4), 395-410.

Tran, T., \& Doan, T. (2010). Industrialization, Economic and Employment Structure Changes in Vietnam during Economic Transition. MPRA Paper No. 26996. 